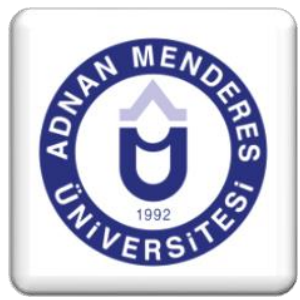

\section{İnsan Kaynakları Programı Çalışma İlişkileri Dersinin Metfessel-Michael Program Değerlendirme Modeline Göre Değerlendirilmesi}

\author{
Kerim GÜNDOĞDU, Mustafa Kemal KOÇ, Sinan \\ BAYIK, Soner ARPAT, Ümit GÖZEL
}

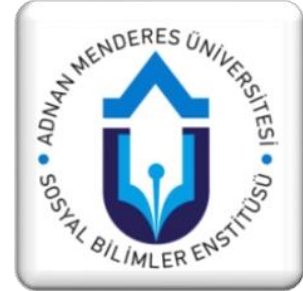

\title{
ÖZET
}

$\mathrm{Bu}$ araştırmanın amacı Adnan Menderes Üniversitesi Sultanhisar Meslek Yüksek Okulu İnsan Kaynakları Programı derslerinden Çalışma İlişkileri ders programını Metfessel-Michael program değerlendirme modeli çerçevesinde değerlendirmektir. Nitel araştırma yaklaşımına dayalı fenomenolojik araştırmada derse yönelik paydaş deneyimleri, görüşleri ve önerileri görüşme ve gözlemler aracılığıyla toplanmıştır. Elde edilen veriler betimsel analiz tekniğiyle çözümlenmiştir. Çalışmaya 15 öğrenci, bir yönetici ve iki öğretim elemanı katılmıştır. Çalışma kapsamında araştırmanın yapıldığı programa ilişkin ülkemizde mevcut durum analiz edilerek dersin içeriği, gerekliliği ve günümüz iş yaşantısı ile uygunluğu, mesleki gelişime katkısı; öğrenme-öğretme durumları ile ölçme değerlendirme süreçlerine ilişkin bulgulara yer verilmiştir. Sonuçlar dersin yer aldığı programa ait çıktıları etkileyen önemli bir ders olduğunu, öğrenme-öğretme sürecinde aksaklıkların yer aldığını, derslerde genellikle anlatım tekniğinin kullanıldığını, konuların teorik olmasının farklı tekniklerle dersin işlenmesini engellediğini ve ölçme değerlendirmede yalnızca sınavlara yer verildiğini göstermektedir. Çalışmada bu bulgulara yönelik önerilerde bulunulmuştur.

Anahtar Sözcükler: Program değerlendirme, Metfessel Michael Modeli, Meslek yüksekokulları, çalışma ilişkileri

\section{Evaluation of Labor Relations Course of Human Resources Program According to Metfessel-Michael Curriculum Evaluation Model}

\begin{abstract}
The purpose of this research is to evaluate Labor Relations course within the Human Resources Program at Adnan Menderes University, Sultanhisar Vocational School, in terms of Metfessel-Michael -program evaluation model. In this qualitative phenomenological research, the experiences of stakeholders towards the course, opinions and suggestions were collected through interviews and observations. The obtained data were analyzed by descriptive analysis technique. The study included 15 students and two faculty members delivering this course, and an administrator. Study analyzed the current situation in our country related to the program. Besides, the research also covered the themes of course content, and compliance with the requirements of today's business life and contribution to professional development; the teaching-learning situations and the assessment process. Results showed that this is a key course that affect the output of the whole program, although it employs several deficiencies in the teaching-learning process. The course usually involved the expository teaching methods that prevents the retention of knwoledge and creates obstacles for effective delivery of the course with different techniques. Measurement process also included formal written exams. Suggestions were made in the study for these findings.
\end{abstract}

Key Words: Curriculum evaluation, Metfessel Michael Model, Vocational high schools, labor relations 


\section{Giriş}

Meslek yüksekokulları iki yıllık bir eğitim sürecine sahip olan ve ülkenin ihtiyacı olan ara insan gücüne farklı iş kollarında uzmanlaşma olanağı sağlayan kurumlarıdır (Davras ve Bulgan, 2012). Meslek Yüksekokullarının insan kaynakları yönetim programı içerisinde yer alan çalışma ilişkileri dersi işveren-işçi ilişkilerini ve tarafların çıkarları ile ilgili birçok düzenlemeyi kapsamaktadır. İçerisinde ekonomi, sosyoloji, psikoloji, hukuk ve siyaset gibi disiplinlerin katkılarını barındıran çalışma ilişkileri, sanayi devrimi sonrasında kötü çalışma koşullarında ve düşük ücretle çalışan işçilerin haklarının aranması problemlerine çözümler üretilmesi amacıyla ortaya çıkmıştır.

Çalışma ilişkileri kavramına alanyazında bakıldığında üretim ilişkilerinin varlığı ile ortaya çıkan, sosyo-ekonomik çevreye göre farklılık gösteren, işçi ve işveren arasında yürütülen ve odak noktası ücret pazarlığı olan kurumsallaşmış ilişkiler bütünü olarak tanımlandığı görülmektedir (Ortakaya, 2015). Bunun yanında çalışma ilişkilerinin aynı zamanda tarafları işçi, işveren ve devlet olan ilişkiler bütünü ve çalışma yaşamına ilişkin kuralların konulmasında tarafların güç mücadelelerini ve aralarındaki etkileşim üzerinde yoğunlaşan bir disiplin olarak da görülmektedir. Çalışma ilişkileri kavramsal boyutta ve tarihsel süreçte incelendiğinde, sanayi devrimi öncesi ve sanayi devrimi dönemi olmak üzere iki temel dönem dikkati çekmektedir (Kağnıcıoğlu, 2007). Bu dönemlerdeki çalışma ilişkileri üretim biçimleri olarak, sosyal tarafların temsili noktasında ve konuların çeşitliliği olarak farklılıklara sahiptir. Literatür ve uygulamalı çalışma ilişkileri alanına makro açıdan bakıldığında, ücretlilerin istihdam ilişkilerinden doğan çalışma hayatının hemen her konusu ele alınmakla beraber işçi-işveren arasındaki ve çalışma hayatındaki tüm ilişkileri incelediği görülebilir. Kısaca çalışma ilişkilerinin başlıca amaçları İşverenler ve işçiler arasında iletişim kurmak; işçi örgütleri arasında iletişim kurmak; işçi-işveren arasında güç dengesini sağlamak ve çalışma koşulları ile ilgili müzakereleri sürdürmek olarak özetlenebilir.

Yukarıda bahsedilenlerin yaşamı sürdürme açısından ne denli önemli olduğu düşünüldüğünde, çalışma ilişkileri alanının insan öğesinin olduğu her platformda ilişkilerin düzenlenmesine, adalete, disipline ve kurallara yapacağı katkı yadsınamaz. İşte bu problemlerin büyümesini engelleyebilecek ve düzenlenmesini sağlayacak faktörlerden biri de insan kaynakları programı ve o programda yer alan çalışma ilişkileri programları ve bu programlardan mezun olacak öğrencilerin verimli biçimde yetiştirilmesidir. Sosyal hayatta bu kadar geniş yer kaplayan bu durum üniversite programlarında kendine nasıl teorik bir zemin bulduğuyla ilgili olarak bu araştırmaya ihtiyaç duyulmuştur. Çalışma ilişkileri dersinin ve insan kaynakları programının hedefleri incelendiğinde, hedeflerin işlevselliğini ve yaşam süreci ile olan ilişkisi görülebilir ve bu program değerlendirme araştırmasında kullanabilecek verilere ulaşılması mümkündür. Adnan Menderes Üniversitesi Sultanhisar Meslek Yüksekokulu İnsan Kaynakları Yönetimi programında yer alan program ve ders hedefleri aşağıda verilmiştir:

-Refah devleti ile sosyal politikanın bağlam ve yapısını anlayabilecek,

-Sosyal politika perspektifinde konut, sosyal güvenlik, sağlik, eğitim ve sosyal hizmetleri kavrayacak,

-Sosyal politikada gelişmeleri ve yeni inisiyatifleri tartışabilecek,

-Sosyal sorunların toplum üzerindeki etkilerini belirleyebilecek,

-Sosyal sorunların etkilerini toplum ve sosyal gruplar üzerindeki özetleyebilecek, bireyler yetiştirmektir (ADÜ, Sultanhisar Meslek Yüksekokulu, İnsan Kaynakları Programı, Çalışma İlişsileri Dersi Bilgi Formu, 2017) 
İnsan Kaynakları Yönetimi Programı'nın hedefleri ise şunlardır (ADÜ, Sultanhisar Meslek Yüksekokulu, İnsan Kaynakları Programı, Çalışma İlişsileri Dersi Bilgi Formu, 2017):

1. İnsan kaynakları yönetimi alanında edindiği ileri düzeydeki kuramsal ve uygulamalı bilgileri kullanabilmek

2. İnsan kaynakları yönetimi alanındaki kavram ve fikirleri bilimsel yöntemlerle inceleyebilmek, verileri yorumlayabilmek ve değerlendirebilmek,

3. Uygulamada karşılaşılan ve öngörülemeyen karmaş1k sorunları çözmek için bireysel ve grup üyesi olarak sorumluluk alabilmek,

4. İnsan kaynakları yönetimi ilgili konularda düşüncelerini ve sorunlara ilişkin çözüm önerilerini yazılı ve sözlü olarak aktarabilmek

5. Düşüncelerini ve sorunlara ilişkin çözüm önerilerini nicel ve nitel verilerle destekleyerek uzman olan ve olmayan kişilerle paylaşabilmek,

6. İnsan kaynakları yönetiminin ilişkili olduğu diğer disiplinlerden yararlanabilmek ve bu disiplinlere ilişkin temel bilgilere sahip olmak

7. Mesleği ile ilgili mevzuatı takip etme ve kamu yönetimi alanında temel hukuk bilgilerine sahip olmak

8. İnsan kaynakları yönetimi ile ilgili verilerin toplanması, planlanması, uygulanması ve denetlenmesi aşamalarında toplumsal, bilimsel ve etik değerlere sahip olmak.

9. Yaşam boyu öğrenmenin gerekliliği bilinci ve bunu gerçekleştirebilme becerisi

10. Ulusal ve uluslararası çağdaş sorunları takip edebilmek

11. Atatürk İlke ve İnkılâplarına duyarlı olabilme, Türk Dilini doğru kullanabilme, temel resmi yazışmaları yapabilme.

$\mathrm{Bu}$ çalışma bu hedeflere ulaşılıp ulaşılmadığı durumuyla ilgili olarak bahsedilen programda yer alan 'Çalışma İlişkileri' ders programının değerlendirilmesini amaçlamaktadır.

\section{Metfessel-Michael Program Değerlendirme Modeli}

Program değerlendirme modelleri adı altında farklı ihtiyaçlardan doğan ve bu ihtiyaçlara cevap vermek amacıyla geliştirilen birçok modele rastlanmaktadır (Uşun, 2012; Yüksel ve Sağlam, 2014. Metfessel-Michael 1960'l1 yılların sonlarına doğru program değerlendirme modellerini Tyler'ın hedefe dayalı değerlendirme modelinden faydalanarak ortaya koymuşlardır (Sönmez ve Alacapınar, 2015). Bu modelde hedefler genelden özele aşamalı olarak sıralanır, sıralanan ve uygun bir şekle dönüştürülen özel hedeflere uygun ölçme araçları geliştirilir, geliştirilen bu araçlarla programda gözlemler yapılır ve veriler toplanır, son olarak da toplanan verilerin analizi yapılır (Michael\&Metfessel, 1967, Akt. Kocabatmaz, 2011). Programla ilgili standartlar ve değerleri açıklanır ve ileriye yönelik uygulanabilirliği konusunda öneriler geliştirmek mümkün kılınır (Demirel, 2007, Akt. Fırat, 2010).

Metfessel ve Michael modelinin en kullanışı yanı, bir eğitim programının hedeflerinin kazanımını yansıtmada kullanılabilecek çeşitli ölçme araçlarının oluşturulmasına yönelik çabalar olarak nitelendirilebilir (Popham, 1988, Akt. Özdemir, 2009). Metfessel ve Michael değerlendirme modelinin sekiz temel aşamasında yer alan ilkelerin farklı kaynaklardaki ortak ifadeleri şunlardır (Fitzpatrick, Sanders ve Worthen, 2004; Michael ve Metfessel, 1967; Ornstein ve Hunkins, 1988; Uşun, 2012; Yüksel ve Sağlam, 2012, Akt. Yakar ve Saracaloğlu, 2016).

Değerlendirme uzmanı;

1. Yöneticiler, öğretmenler, öğrenciler ve vatandaşların değerlendirme süreçlerinde dolaylı ya da doğrudan yer almasını sağlamalıdır.

2. Hedefleri genelden özele doğru aşamalı olarak sıralamalıdır. 
3. İkinci madde oluşturulan özel hedefleri programda uygulanabilir bir biçime dönüştürmelidir.

4. Belirlenen hedeflerin dışında programın etkililiğini bireyler açısından ölçebilecek ölçme araçları geliştirilmelidir.

5. Programın uygulandığı sürece test ve diğer ölçme araçlarını kullanarak düzenli gözlemler yapılmalıdır.

6. Toplanan veriler analiz edilmelidir.

7. Programı felsefi anlamda değerlendirmede kullanılabilecek standartlar ve değerleri açıklamalıdır.

8. Toplanan verilere dayalı olarak programın ileriye yönelik uygulanabilirliği konusunda öneriler geliştirmeli ve ayrıca programın genel ve özel hedefleri ile eğitim durumunun (öğrenme yaşantıları ve araç-gereçlerin) genel değerlendirmesi de yapılmalidir.

Yukarıda belirtilen açıklamalar doğrultusunda Metfessel-Michael program değerlendirme modelinin program değerlendirme uzmanlarına okul programlarının değerlendirilmesi hususunda rehber olacağı söylenebilir (Uşun, 2012). Programın değerlendirilmesinde idareciler, öğretmenler, öğrenciler, veliler ve okul çalışanları da etkilidir. Dolayısıyla modelde eğitim dünyası içinde yer alan tüm bireylerin doğrudan veya dolaylı bir şekilde değerlendirmeye katılmaları sağlanmalıdır. (Demirel, 2007, Akt. Fırat, 2010). Onlarında görüşleri dikkate alınmalı ve değerlendirme aşamasında kullanılmalıdır. Bu çalışmanın amacı, ülkemizde son y1llarda ön lisans düzeyinde tercih edilen programlar arasında yer edinmeye başlayan iki yıl süreli eğitim veren İnsan Kaynakları Programına ait Çalışma İlişkileri ders programını Metfessel-Michael değerlendirme modeline göre incelemektir.

\section{Yöntem}

$\mathrm{Bu}$ araştırma nitel bir anlayışa dayalı olarak yapılmıştır. Nitel araştırma yaklaşımı, incelenen bir duruma ya da olguya yönelik ayrıntılı bilgi toplamayı, bununla beraber derin bir anlayış geliştirmeyi ve ortaya konan durumu kendi içerisinde açıklamayı amaçlamaktadır. $\mathrm{Bu}$ çalışmada, nitel araştırma desenlerinden araştırmanın doğasına uygun olan 'olgubilim (fenomenoloji) deseni' kullanılmıştır. $\mathrm{Bu}$ desen katılımcıların deneyimlerinin neler olduğuna, bunları nasıl tanımladıklarına ve bu deneyimin onları nasıl etkilediğini odaklanır (Patton 1990). Kısacası olgubilim deseni farkında olduğumuz, ancak derinlemesine ve ayrıntılı bir anlayışa sahip olmadığımız olgulara odaklanmaktadır (Yıldırım ve Şımşek, 2016).

$\mathrm{Bu}$ çalışma kapsamında, nitel araştırma yöntemlerinden; görüşme, gözlem ve doküman incelemesi teknikleri kullanılmıştır. Farklı nitelikte ve derinlikte veri toplama yöntemi olarak kullanılan görüşme, araştırmacı ile araştırmanın merkezinde yar alan katılımcının arasında geçen kontrollü ve amaçlı sözel iletişim biçimidir (Cohen ve Manion, 1994:27). Bu sebeple araştırmacı, bu yöntemi kullanarak görüşme yaptığı bireyin dünyasına girer ve olaylara onun gibi bakıp anlamaya çalışır (Patton, 1987: 109). Diğer araştırma teknikleriyle ulaşılamayan bazı duruma özel ve kapalı birçok özelliği bu teknik kullanılarak ortaya çıkarılabilir (Kvale, 1996: 1).

Nitel araştırmada kullanılan diğer bir bilgi toplama yöntemi ise gözlemdir. Gözlemler yoluyla doğrudan ve olayın cerayan ettiği doğal ortam içinde bilgi toplama geçerliği arttıran etkenlerdir (Yıldırım ve Şimşek, 2016). Bu kapsamda yapılan çalışmanın geçerliğini arttırmak için doğal ortam içerisinde gözlemler yapılmıştır. Yazılı doküman ve belgelerin analizi nitel araştırmada görüşme ve gözlemle toplanıp elde edilen verilere destek amacıyla kullanılan bir yöntemdir. Araştırmada elde edilen veriler de çeşitlilik gösterebilir. Bular 
gözlem notları, görüşme kayıtları, dokümanlar, resimler ve diğer grafik sunumlar şeklinde sıralanabilir. Bahsi geçen görüşme, gözlem ve doküman analizi yöntemleriyle elde edilen verilerin kodlanması, analizi ve yorumlanması ise düzenli bir yaklaşımı gerektirir (Coffey ve Atkinson, 1996; Wolcott, 1994).

\section{1. Çalışma Grubu}

Araştırma Adnan Menderes Üniversitesi, Sultanhisar Meslek Yüksek Okulu, Yönetim ve Organizasyon Bölümü, İnsan Kaynakları Yönetimi Programı özelinde gerçekleştirilmiştir. Çalışmada tamamen gönüllülük esas alınmış ve 'Çalışma İlişkileri' dersini veren 2 öğretim elemanı, 1 yönetici ve dersi alan 15 öğrenci olmak üzere toplam 18 kişinin katılımı sağlanmıştır.

Tablo 1. Katılımc1ların Özellikleri

\begin{tabular}{lcccc}
\hline Unvanı & Kişi Sayısı & Cinsiyeti & Yaşı & Mesleki Deneyimi \\
\hline Yönetici & 1 & Erkek & 35 & 10 Yıl \\
\hline \multirow{2}{*}{ Öğt. Elemanı } & 1 & Erkek & 35 & 8 Y1l \\
& 1 & Kadın & 31 & 6 Yıl \\
\hline & Erkek & 18 & - \\
& Erkek & 19 & - \\
& & Erkek & 19 & - \\
& Erkek & 20 & - \\
& Erkek & 21 & - \\
Öğrenci & Kadın & 18 & - \\
& & Kadın & 18 & - \\
& Kadın & 19 & - \\
& Kadın & 19 & - \\
& \multirow{2}{*}{15} & Kadın & 19 & - \\
& & Kadın & 19 & - \\
& & Kadın & 21 & - \\
& & Kadın & 21 & - \\
& Kadın & 22 & - \\
& & Kadın & 24 & - \\
\hline
\end{tabular}

\subsection{Veri Toplama Araçları}

İdareci, öğretim elemanı ve öğrenciler ile yapılan görüşmelerde yarı-yapılandırılmış görüşme formları kullanılmışıır. Gözlem kısmında ders içeriği 2 hafta ve 8 ders saati boyunca bağımsız bir araştırmacı tarafından gözlem formları kullanılarak gözlenmiş̧tir. Ayrıca doküman analizi olarak program bilgi formu, ders bilgi formu, program teklif dosyası ve öğretim elemanlarının derste kullandıkları yazılı materyaller incelenmiştir.

Nitel verilerin toplanması amacıyla öncelikle araştırmacıların katılımlı gözlem yapabileceği bir form oluşturulmuş ve "ders gözlem formu" şeklinde adlandırılmıştır. Gözlem, herhangi bir ortamda ya da kurumda oluşan davranışı ayrıntılı olarak tanımlamak amacıyla kullanılan bir yöntemdir. Ancak gözlem, basit anlamda, sadece normal durumlarda s1k olarak görülmeyen davranışları ortaya çıkarmak için kullanılmaz. Eğer bir araştırmacı, herhangi bir ortamda oluşan bir davranışa ilişkin ayrıntılı, kapsamlı ve zamana yayılmış bir resim elde etmek istiyorsa, gözlem yöntemini kullanabilir (Bailey, 1982). Alanında uzman bir öğretim görevlisi, 2 hafta ve 8 ders saati boyunca derslere girerek, öğrenme - öğretme sürecini, öğrencilerin derse katılımını ve dersin içeriğini gözlemlemiş ve hazırlanan gözlem formunu doldurmuştur. 
İkinci olarak, dersi veren 2 öğretim eleman1, 1 yönetici ve 15 öğrenci ile Sultanhisar Meslek Yüksekokulunda; öğretim elemanları ve yöneticilerle odalarında, öğrenciler ile boş dersliklerde kendi rızaları alınarak ses kaydı içeren yüz yüze görüşmeler yapılmıştır. Görüşme tekniğinde verileri toplamak için, bireylerin bakış açılarını ortaya çıkarma ve düşünce yapıları içerisinden istenilen bulguları elde etme arayışı söz konusudur. Deneyimler, tutumlar, düşünceler, niyetler, yorumlar, zihinsel algılar ve tepkiler gibi gözlenmesi zor olan davranışların, görüşme vasıtasıyla ortaya çıkarılması amaçlanır. Bu süreçte amaç görüşülen kişinin sorulara içtenlikle ve ayrıntılı yanıt vermesini sağlamaya çalışmaktır (Yıldırım ve Şimşek, 2016). Görüşmeler gerçekleştirilirken, 4 araştırmacı ve 1 alan uzmanı tarafından hazırlanan yarı yapılandırılmış görüşme formları kullanılmıştır. Çalışma İlişkileri dersine yönelik geliştirilen öğretim programı dokümanları ise ayrıca incelenmiştir. Doküman incelemesi, araştırılması hedeflenen olgu veya olgular hakkında bilgi içeren yazılı materyallerin analizini kapsar.

\subsection{Verilerin Analizi ve Yorumlanması}

Çalışma İlişkileri dersine katılarak yapılan gözlemlerden ve Çalışma İlişkileri dersine ilişkin öğretmenlerin, yöneticilerin ve ögrencilerin görüşlerinden elde edilen nitel veriler, betimsel analiz tekniği ile çözümlenmiştir. Betimsel analizde elde edilen veriler karşı tarafa etkili bir şekilde aktarılmaya çalışıldığı için doğrudan alıntılara sık sık yer verilir. Bu analiz yönteminde amaç elde edilen verileri düzenlenmiş ve yorumlanmış bir şekilde okuyuculara sunmaktır (Yıldırım ve Şimşek, 2016). Araştırmada elde edilen nitel veriler, Çalışma İlişkileri dersi öğretim programının Metfessel-Michael program değerlendirme modeline göre değerlendirilmesi amacıyla kullanılmıştır.

\section{Bulgular}

\section{1. İnsan Kaynakları Yönetimi Programının Ülkemizdeki Mevcut Durumu}

Araştırmamıza katılan 1 yönetici (Y) ve 2 öğretim elemanının (Ö.E.), İnsan Kaynakları Programının ülkemiz eğitim ve iktisadi yapısı içerisindeki durumu özetleyen soruya verdikleri cevaplar, ülkemizde İnsan Kaynakları programlarına yeni yeni önem verilmeye başlandığını ortaya koymaktadır. Katılımcılar İnsan Kaynakları Programının iş gücü, istihdam verimliliği, profesyonelleşme, iktisadi yapıya katkı ve maliyet avantajı gibi iş dünyasına olumlu etkileri olduğunu düşünmektedir. Büyük şirketlerin yanı sıra küçük ve orta ölçekli işletmelerin de insan kaynakları yönetimini tercih ettiklerinin görülmeye başlandığ dile getirilmiştir.

Ders bilgi formu incelendiğinde derin öğrenme çıtıları ile programın öğrenme çıktıları arasındaki ilişki beşli değerlendirme tipine göre değerlendirilmiş ve ders öğrenme çıtılarının programın genel öğrenme çıktılarına etkisinin yüksek olduğu ilgili ders bilgi formu ve program bilgi formunun doküman incelemesinden anlaşılmıştır. Bu konuya ilişkin ileri sürülen bazı görüşler aşağıda verilmiştir:

Bence ülkenin iktisadi anlamda iş gücünü daha iyi kullanması açısından çok önemli bir program, yavaş yavaş da firmaların çoğunda insan kaynakları kavramı oturmaya başladı. Eskiden bunlar personel yönetimi adı altında geçer ve genel çalışanlar personele de bakarlardı, bu kanı artık yıkılmaya başladı, İsgücü ve istihdamın verimliliği için bu anlamda profesyonelleşme başladı. Bu açıdan ayrıca programın istihdam olanağı olarak da önünün açık olduğunu ve ülkemiz iktisadi yapısına katkısı olduğunu düşünüyorum (Ö.E-1). 
Türkiye'deki ticaret hacminin genellikle büyük çaptaki aile şirketleri olduğu, bunun dışında kalan orta ve küçük işletmelerinde artık insan kaynakları yönetimini tercih ettiğini görüyoruz. Isslerin artık daha profesyonel düzlemde bu şekilde gerçekleştirilmesinin de ülkemiz iktisadi yapısına katkı yaptığını düşünüyorum (Ö.E-2).

İnsan Kaynakları Programının yaşam boyu öğrenmeyi desteklediği, nitelikli iş gücü sağladığı, emeğin iyi yönetildiği, doğru yönlendirildiği ve bu sayede ülkemiz iktisadi yapısına sağladığı katkı katılımcıların çoğu tarafından dile getirilmiştir. Ayrıca personelin elde tutulması, değerlendirilmesi, geliştirilmesi ve işletmeye katkı sağlaması açısından da İnsan Kaynakları Programının önemine vurgu yapılmıştır. Bu konuya ilişkin bazı görüşler şu şekildedir:

Emek de kiralanan bir kaynaktır ve emeği iyi yönetebilmek, emekten beklentilerinizin tamamın alabilmek, emeği doğru yönlendirebilmekte işletme açısından maliyet avantajı sağlayacaktır $(Y)$.

Türkiye'de yetişkin iş gücünün içerisindeki kalifiye personellerin değerlendirmesinin bu departman sayesinde olmasının da ülkemiz makro ekonomik göstergeleri açısından iyi olduğunu düşünüyorum (Ö.E-2).

\subsection{Dersinin İçeriği Ve Gerekliliği}

Araştırmaya katılan katılımcıların tamamı Çalışma İlişkileri dersinin iş dünyası için önemini ortaya koyacak fikirler belirtmişlerdir. Öğrencilerin, işveren ve işçi arasındaki yasal düzenlemeleri algılamasını sağladığını ve Çalışma İlişkileri dersinin, İnsan Kaynakları Programının en önemli derslerinden biri olduğunu dile getirmişlerdir. Bunun ana nedeni olarak da içeriğin tamamen öğrencileri iş yaşamına hazırlama yönelik olması belirtilmiştir. Ayrıca dersin içeriğinin Bunun yanı sıra içeriğin güncelliği ile ilgili soruya öğretim elemanlarından biri yeterince güncel değil vurgusu yaparken; diğer öğretim elemanı içeriğin her dönem öncesi yapılan "Akademik Değerlendirme Toplantılarında" tartışılıp güncellendiğini dile getirmiştir.

Bu konuya ilişkin görüşlerden bazıları şunlardır:

IK Yönetimi Programının içeriği 2011 yılında tarafimca, DGS ile lisans tamamlaması yapacak ögrrencilerin mağdur olmaması için Sakarya Üniversitesindeki dönemin tek lisans bölümü derslerine uygun şekilde hazırlanmıştır. Aradan geçen 6 yll boyunca kayda değer her hangi bir güncelleme yapilmadl, paydaşlar ile bir araya gelinmedi ve mezun ögrencilerden görüs alınmadı.(Ö.E-1).

Program içerikleri dersi veren hocalar ve diğer hocalar tarafindan her yartyll yapılan akademik değerlendirme toplantılarında tartışılır ve güncellenir. Kaldı ki dinamik bir ders olduğu için bu alandaki yasa ve yönetmeliklerin güncellemelerinin takibi zaten bunu zorunlu kılar. Mevcut haliyle günceldir (Ö.E2).

Çalışma ilişkileri dersi işveren ile işçi arasındaki yasal düzenlemeleri bu departmanda çalışacak ögrencilerimizin tam olarak algılamasını sağlar. Öğrencilerimiz iş hayatına girdiklerinde devletin getirmiş olduğu yasal gerekçeler karşısında çalışanların nasıl davranması gerektiği, işverenlerin yasal yükümlülükleri konusunda çallşanla işveren arasında bir köprü vazifesi görmesi açısından programın önemli derslerinden birisidir $(Y)$. 
Öğrencilerin dersin içeriğine yönelik bakış açıları genel anlamda olumludur. Öğrencilerin büyük çoğunluğu meslek yaşamlarında kendileri için çok önemli olan işçi hakları ve işveren sorumlulukları ile ilgili kanunları öğrendiklerini, işçilerin çalışma saatleri ile ilgili bilgi sahibi olduklarını belirtmişlerdir. Bu konuya ilişkin bazı öğrenci görüşleri şöyledir:

\section{İs, iş̧̧i ve işveren hakkanda kanunlarl yer edinen bir derstir. Bu paydaşlar} arasındaki ilişkinin hukuki dayană̆ını öğrendiğimiz bir derstir (Ö-2).

Dersimiz genel olarak çalışanların, işletmelerde, fabrikalarda ve bilumum farklı kurumlarda çalışanların işverenlerle karşılıklı hakları ve sorumlulukları üzerinedir $(\ddot{O}-3)$.

Isş̧ini ve işverenin kanunlarda belirtildiği üzere yönetilmesi gerektiğini ögrrendim. Isş̧i ve işveren hakkında yürürlükte olan kanunları ayrıca detaylıca öğreniyoruz. Haklarını bilmeyen işçilerin yaşadıkları sorunları tartışı öğreniyoruz (Ö-10).

\subsection{Ders İçeriğinin Günümüz İş Yaşantısı İle Uygunluğu}

Çalışma İlişkileri dersinin içeriğinin, iş yaşamına uygunluğu ile ilgili soruya, öğretim elemanlarının ikisi de kanunen uygun olduğunu cevabını vermiştir. Ama günlük iş yaşantısındaki sıkıntılar ve işverenlerin kanunlara uyma konusunda bazen gayri hukuku davranması, öğrencilerin derste öğrendikleri ile gerçek hayatta yaşadıklarının çelişmesine neden olduğunu da dile getirmişlerdir. Bu konuya ilişkin görüşlere bakarsak:

Ders içeriği, içeriği oluşturan 4857 sayll İ̧̧ Kanununa uygundur ancak günlük iş yaşantısı kanuna uygun değildir. Temel sorunlar da burada çıkmaktadır. Mevzuatı öğrenen her öğrenci, gerçek hayatta bu koşulların var olmadı̆̆ını ya da insanların haksızlı̆̆a uğradı̆̆ını ifade ederek ikilem yaşamaktadır (Ö.E-1).

Ders içeriği kanuna uyumludur ve hedefler buna göre güncellenmektedir ancak, günümüz iş yaşantısında bazı gayri hukuki durumların ortaya çıkması ögrencilerin kafa karışıklı̆̆ına sebep olmaktadır (Ö.E-2).

Görüşmeye katılan öğrencilerin büyük çoğunluğu, Çalışma İlişkileri dersinin içeriğinin günümüz iş yaşantısına uygun olduğunu düşünmektedir. Dersin mevzuat takibine dayandığı, günümüz iş yaşantısından örnekler verildiği, çalışma hayatında uyulması gereken kurallar ile iş yeri kurallarının aynı olduğu, bu düşünceyi besleyen görüşlerden birkaçıdır. Buna karşın öğrencilerden birkaçı, dersin içeriğinin iş yaşantısına uygun olmadığını düşünmektedir. $\mathrm{Bu}$ düşüncenin olgunlaşmasında, işyeri kurallarının daha katı olması, işverenlerin adaletli davranmadığı, teorik bilgiler ile gerçek hayatın birbirinden oldukça farklı olması gibi görüşler yer almaktadır. Bu konuya ilişkin bazı öğrenci görüşleri şöyledir:

Evet. Kanunlara uygun çalışlyor. Ders zaten mevzuat takibine dayanıyor. Kanunlar ve gelişmeler takip edilip güncel halde bize aktarlliyor (Ö-1).

Bir sürse bir fabrikada yönetimde gözlem yapma imkânım oldu. Burada ögrendiğimiz her bilgiyi yönetim içinde önemli bir yeri var. Kesinlikle hayatın içindeki konulardır diye düşünüyorum (Ö-3).

Hayır düşünmüyorum. Günümüz iş yaşantısı ders içeriğinden daha katı olduğunu düşünüyorum (Ö-2).

\subsection{Dersin Öğrencilerin Mesleki Gelişimine Etkisi/Katkısı}

Çalışma İlişkileri dersinin, öğrencilerin mesleki gelişimine çok olumlu etkileri olduğu, öğretim elemanları ve yönetici tarafından dile getirilmiştir. Öğretim Elemanları 4857 sayılı 
İş Kanununa göre, öğrencilerin sorumluluklarını, haklarını ve ödevlerini bilmeleri açısından bu dersin büyük önem taşıdığını belirtmişlerdir. Bu konuya ilişkin bazı görüşler şöyledir:
IK biriminde çalışacak öğrencilerin, 4857 sayılı İ̧̧ Kanununa göre sorumlulukları, ödevleri ve haklarını bilmeleri ve ayrıca her çalışanın bu sorumluluk, ödev ve haklara sahip olduğunun farkında olarak çalışması gerekmektedir. Aksi takdirde gerçekleştirdikleri veya gerçekleştirmedikleri eylemlerden nasıl bir hukuku veya sosyal sonuç açığa çıkar, bilmeleri mümkün değildir (Ö.E-1).
İş̧i ve işveren arasındaki hukuki zeminin oluşturulması mantığının anlaşılması açısından oldukça etkilidir. Çünkü bu zemindeki kurallar dâhilinde düzenlenen bir iş yaşantımız var (Ö.E-2).

Öğrencilerin bu konuya yaklaşımları da öğretim elemanlarının düşüncelerine benzer nitelikler taşımaktadır. Öğrenciler, bu derste öğrendikleri bilgilerin, gelecekteki meslek yaşantıları için çok önemli görmektedirler. Öğrencilerin büyük çoğunluğu, mesleki gelişimlerine çok olumlu katkılar sunduğunu ve iş dünyasında çalışan her paydaşın bu dersin içeriğine hakim olması gerektiğini vurgulamışlardır. Bu konuya ilişkin bazı öğrenci görüşleri aşağıda yer almaktadır:

İşverenler ve çalışanların hakkından bahsettiği için bence olmazsa olmaz bir dersimizdir. Ayrica ileride çalışan olduğumda haklarımı savunabilmeliyim. İsveren olduğumda da çalışanlarımın haklarını verebilmem için bana çok yardımcı olacağını düşünüyorum (Ö-14).

Bu bölümde çalışma ilişkileri dersi, mesleki gelişimimde en etkili bir derstir diyebilirim. Mesleki anlamda, kişilik ve mesleki gelişimimize çok fayda sağladığını ve sağlayacağını düşünüyorum (Ö-10).

Bilinçli bir şekilde çalışacağım ve hakkımı yemelerine izin vermeyeceğim. Çalışanın, işçinin, işverenin, yönetenin $v b$. hak ve sorumluluklarını öğrendiğim için kendimi şanslı hissediyorum (Ö-6).

\section{5. Öğrenme-Öğretme Durumları}

Öğretim elemanlarının ikisi de dersin öğrenme etkililiğini arttırmak için yaşanmış örnek olaylardan faydalandıklarını belirtmişlerdir. Ayrıca öğretim elemanlarından biri, öğrencileri soru sormaya zorladığını, sınava yönelik sorular ile öğrencilerin ilgilerini çekmeye çalıştığını, dersin nitelikli geçmesi için devam zorunluluğu aramadığını ve öğrencilere her türlü iletişim imkânı yarattığını dile getirmiştir. Bu konuya ilişkin öğretim elemanlarının görüşleri şöyledir:

Yaşayan ve hayatın içerisinden bir ders olduğu için yine iş hayatının içerisinden örnek olaylar üzerinden ders işlenmektedir. Bununla ilgili gazete, dergi haberleri, iş mahkemesi davaları gibi malzemeler etkin biçimde değerlendirilmektedir (Ö.E-2).

Ders ile ilgili özellikle ögrencilerin konuları tekrar ederken, slnava soru hazırliyorlarmış gibi basitten zora doğru sürekli soru evirmelerini istemekteyim. Böylece sorudan soru üreterek sürekli gelişen ve düşünmeyi zorunlu kllan bir çalışma sistemine sahip olmalarını amaçlamaktayım. Bunun dışında gerçek olaylardan, güncel durumlardan hazlrlanan örnekler veya sinav sorularl ile ilgilerini konuya çekmeye çalışmaktayım. Whatsapp grubu, e-posta veya sosyal medya hesapları ile diledikleri zaman sorularını sormayı mümkün kılarak iletişim 
kolaylı̆̆l yaratmaya çalışmaktayım. Ayrıca artan ögrenci kontenjanının derste ögrenci ile kaliteli iletişim kurma konusunda ortaya çıkardı̆̆ olumsuzluklardan dolayl, devam zorunluluğunu sadece sinavlara girme olarak belirlemekteyim. Böylece sadece eğitim ihtiyacı olan ya da eğitime kendi isteği ile gelenlerin varlığı sayesinde ders kalitesi artmakta ve ortalama 20-25 kişi ile ders yürütülmektedir (Ö.E-1).

Öğrencilerin öğrenme - öğretme durumlarının etkililiğine yönelik düşünceleri, öğretim elemanlarının düşünceleri ile tezatlık göstermektedir. Görüşülen öğrencilerden sadece biri durumdan memnun olduğunu dile getirirken, diğer öğrenciler öğrenme yöntem ve tekniklerinin çeşitlendirilmesi yönünde görüş belirtmişlerdir. Bu görüşlerin içinde en çok göze çarpanı, iş yerlerine gezi yapılması isteğidir. Bunun dışında görsellerden, kısa filmlerden faydalanılması gerektiği, uygulamalara daha çok yer verilmesi gerektiği gibi fikirler de ön plana çıkmıştır. Bu konuya ilişkin bazı öğrenci görüşleri şöyledir:

Şirketlere yani büyük sektörlere gezi yapılsa daha iyi olabilir. Tiyatro yaparak, konuları canlandırarak anlatılsa daha iyi olur (Ö-5).

Ben beğeniyorum ve anllyorum ekstra bir şey yapılmasına gerek duymuyorum (Ö-6).

Deneyler klsa film olarak bizlere aktarılabilir. Uygulamalı eğitime ăgırlı verilmelidir. Şirketlere geziler düzenlenip gözlem yapmamız sağlanabilir (Ö-10).

Ders ile ilgili özel ya da kamu sektöründen alanında bilirkişilerle seminer organizasyonlart yapllabilir $(\ddot{O}-13)$.

\section{6. Ölçme-Değerlendirme Süreci}

Öğretim elemanlarının değerlendirme ölçütlerini nasıl yaptıklarına dair sorulan soruya benzer cevap vermişlerdir. Öğretim elemanları, üniversitenin belirlemiş olduğu şekilde, bir ara sınav (\%40) bir de final (\%60) ile dönem değerlendirme yaptıklarını belirtmişlerdir. Ayrıca sınavlarda açık uçlu sorulardan faydalandıklarını söylemişlerdir. Bu konuya ilişkin öğretim elemanı görüşü:

Dersi alan ögrenciler, üniversitemizin belirlemiş olduğu ölçme araçları olan bir ara sinav (\%40) ve bir yartyll sonu sinavi (\%60) ile değerlendirilmektedir. Ayrica sinavlarda açık uçlu soruları kullanmaktayız (Ö.E-2).

Öğrencilerin değerlendirme ölçütlerine yaklaşımı birbirinden farklılık göstermektedir. Bazı öğrenciler değerlendirmenin sadece sınav ile yapılmasına karşı çıkarken, bazı öğrenciler de sınavların erken saatlerde yapılmasından şikâyet etmektedir. Bazı öğrenciler çoktan seçmeli soruların da olması gerektiğini söylerken, çok az öğrenci de mevcut durumdan memnun olduklarını dile getirmişlerdir. Bu konuya ilişkin çeşitli öğrenci görüşleri şöyledir:

Zor fakat gerekli olduğunu düşünüyorum. Öğrenciyi tüm konulardan sorgulayan bir değerlendirme aşaması geçiriyoruz (Ö-1).

Sinav cevaplarını bildiğim halde soruların karmaşık yapısından dolayı soruyu anlayamiyorum ve dolaylslyla cevaplayamiyorum. En azından ilk sinavlar test olabilir $(\ddot{O}-2)$.

Örgün ögretimlerin sabah ders saatleri çok erken olduğu için verim alamıyoruz, uykumuz geliyor. Bu da sinavlara olumsuz etki yapıyor (Ö-4). 


\section{Bizler bir bireyiz. Her şey kâğıt parçası değildir. Ödev de verilmelidir. Alternatif değerlendirme şekilleri olabilir diye düşünüyorum (Ö-7).}

Eksiklikler olduğunu düşünüyorum. Değerlendirmede açı uçlu sorularla ölçme yapıllyyor. Çoktan seçmeli sinavlar gerçekleştirilebilir (Ö-8).

Dersler ayrıca araştırmacılar çeşitli yapılandırılmamış gözlemler yaparak yaptıkları gözlemleri bir form üzerinde kaydetmişlerdir. Gözlemler sırasında derste 'dikkat çekme'nin orta düzeyde kalması, öğreten ve öğrenen arasında durağan/pasif bir ilişki kurulması ve motive edici bir unsur oluşturulamaması, dersin aktarılması ile ilgili bir eksiklik olarak not edilmiştir. Tüm bu durumlar öğrencilerle ders süreciyle ilgili yapılan görüşmeleri doğrular niteliktedir.

\section{Sonuç ve Tartışma}

Ülkemizde Metfessel-Michael program değerlendirme modeline göre gerçekleştirilen çalışmalar sınırlıdır. Özellikle ara insan gücü gereksinimine karşılık veren meslek (yüksek)okullarına ait araştırmalara göz atıldığında, bu araştırmaya da konu olan İnsan Kaynakları Programlarına ait çalışmalar yok denecek kadar azdır. Çalışma İlişkileri dersinin değerlendirilmesi ile ilgili herhangi bir çalışmaya da yine rastlanılmamıştır. Çalışma ilişkileri dersinin ülkemiz ekonomik yapısı içerisinde küreselleşme normları da göz önüne alındığında, İnsan Kaynakları Programı için önem arz eden ve rasyonel tabana sahip bir ders olduğu anlaşılmaktadır. Özellikle işgücü, istihdam verimliliği, profesyonelleşme, işçi hakları, işveren sorumlulukları gibi çalıșma hayatının olmazsa olmaz öğelerini kucaklayan ve kavramlar arasındaki örüntüyü bir arada ayakta tutabilen bir yapı olduğu da söylenebilir. Bu araştırmada Metfessel-Michael program değerlendirme modelinin temel aşamalarına özellikle dikkat edilmiş ve programın paydaşlarının görüşlerinin değerlendirme sürecine katkı sağlamasına çalışılmıştır. Dersin öğrenme çıtıları ile programın öğrenme çıktıları arasındaki ilişkilendirme bağlantısı, ilgili dokümanlar üzerindeki inceleme ile ortaya konmuş ve yüksek bir ilişki düzeyi gözlenmiştir. Dolayısıyla dersin program kazanımlarını yüksek derecede etkileyen önemli çıktılara sahip bir ders olduğu anlaşılmaktadır.

Çalışma İlişkileri dersi ile ilgili olarak çalışmada kazanımlar göz önünde bulundurulduğunda, öğrenme - öğretme süreci ile ilgili aksaklıklar yaşandığı ve bu eksikliklerin dersin hedeflerine ulaşılmasını engellediği görülmektedir. $\mathrm{Bu}$ açıdan değerlendirildiğinde, dersin öğretim programının öğrenmeyi artırmak için öğrenme-öğretme etkinlikleri açısından zenginleştirilmesi gerektiği araştırmacılar tarafından not edilmiştir. Metfessel-Michael program değerlendirme modelinin temel aşamalarında belirtildiği gibi, araştırmacılar tarafindan yapılan düzenli ders içi gözlemler ve yapılan görüşmelerden elde edilen bulguların analizi sonucunda bu durumu destekleyen bulgular ortaya çıkmıştır. Görüşülen öğretim elemanları bu konuda kendilerini yeterli hissettiklerini ifade ederken; öğrencilerin neredeyse tamamının öğrenme - öğretme süreci ile ilgili mevcut durumdan bazı rahatsızlıkları olduğuna dikkati çekmişlerdir. Süreçte öğrenmelerin daha kalıcı olması için getirdikleri öneriler, günümüz modern eğitim anlayışının gereklilikleri arasında yer aldığı görülmektedir. Bu durumda yeni bir düzenleme yapılması, öğrenme - öğretme sürecinin görsellerle ve örnek olay içeren videolarla zenginleştirilmesi, büyük firmalara yapılacak geziler, iş dünyasından kendini kanıtlamış kişilerin okulda verecekleri seminerler; hem öğrencileri derse karşı daha çok motive ederken, hem de öğrenme - öğretme sürecinin etkililiğini artıracağı açıktır. Bunun yanı sıra belli senaryolar üzerinden etkileşimli bir öğrenme ortamı yaratılarak, öğrencilerin öğrenme sürecine aktif bir șekilde katılmas1 sağlanabilir. Bu durum öğrenmelerin kalıcı hale gelmesini ve de öğrenme sürecinin daha 
eğlenceli geçmesini sağlayacaktır. Ancak yapılan ders içi gözlemler ile öğretim elemanı ve öğrenci görüşmelerinin 1şığı altında, derslerde, öğretim elemanının farklı öğretim materyalleri kullanmadan, 'anlatım' yoluyla dersleri sunduğu ve soru cevap etkinlikleriyle de zenginleştirmeye çalıştığ görülmüştür. Bu durum öğrenmenin etkililiğini sınırlayan önemli bir eksiklik olarak görülebilir. Buna benzer olarak, Yakar ve Saracaloğlu'nun (2013) yine Metfessel-Michael değerlendirme modeli kapsamında gerçekleştirdiği çalışmasında da belirtildiği gibi yeni ve farklı etkinliklere ihtiyaç duyulduğu; içerik, öğrenme-öğretme süreci ve değerlendirme boyutlarında benzer aksaklıklar yaşandığı bulgusuyla örtüşmektedir. Farklı okul düzeylerinde yapılan program değerlendirme çalışmalarındaki bulgularla benzerlik göstermektedir. Tüm bu bulgular göstermektedir ki, programların çağdaş ilkeler ışığı altında geliştirilmiş olması, ‘öğretmen' faktörünün de bu paralelde yetiştirilmiş olmasını zorunlu kılmaktadır.

Dersin öğrenme çıktıları gereği yapılandırılmış olan konular hukuki yani var olan normlara dayandığ gözlenmiş̧ir. Ancak bu aşamada derste öğretilen resmi normlar ile informal yolla gerçekleşen öğrenmeler çatışma içerisinde bir görünüm sergilemektedir. Bu çatışmaların çözümlenmesi ve formal öğrenmenin desteklenmesi için dersle ilgili bu hukuki normları destekler nitelikte uygulama çalışmaları ve örnek olay incelemelerinin derse entegre edildiği anlaşılmaktadır. $\mathrm{Bu}$ çalışmaların öğrenme motivasyonu ve kalıcılığı artırabilmek için etkileşimli hale getirilmesi, gerçek hayattan kesitler sunulabilecek öğrenme ortamlarının oluşturulması, öğrencilerin öğretimle ilgili sürece gösteri, drama gibi yöntemlerle aktif olarak dâhil edilmesi, dersin hedeflerinin ulaşılabilirliğini artırıcı çalışmalar olarak görülmektedir. Bununla beraber, ders içeriği ve öğrenci ifadelerinden anlaşıldığı üzere, ders genelde teorik bir öğrenmeyi gerektirdiği için, zinde ve açık bir zihne gereksinim duymaktadır. Ders saatlerinin öğrencilerin zihinsel aktivite düzeylerinin yüksek olduğu aralıklara yerleştirilmesinin etkili öğrenme düzeyini artıracağı öğrencilerle yapılan görüşmelerden anlaşılmaktadır. Ayrıca dersi anlatan öğretim elemanın sınıf içinde niteliği artırmak ve içsel motivasyonu yüksek bireylerin eğitim alacağı bir yapı oluşturmak ve bu sayede nitelikli bir iletişim ortamı yaratmak için derste devam zorunluluğu aramaması dikkat çekici bulunmuştur. $\mathrm{Bu}$ duruma göre öğrenci üzerinde katılım sorumluluğunun hissedilmesinin ders içinde de motivasyonu artırıcı bir olgu olarak düşünülebilir. Buna benzer olarak Çakıcı (2010), 'Mesleki Eğitim Merkezlerinde Uygulanmakta Olan Erkek Berberliği Eğitim Programının Değerlendirilmesi' adlı çalışmasında, öğrenci ve öğretmenlerin programa isteyerek katıldıklarını ve öğretim programından genel anlamda memnun olduklarını tespit etmiştir. Bu durumun öğrenmeyi kalıcı hale getiren temel etmenlerden biri olduğunu da ayrıca belirtmiştir.

Dersin değerlendirme aşamasındaki normların öğrenme-öğretme sürecinin yukarıda belirtildiği üzere organize edilmesi halinde tekdüze kaldığı görülmektedir. Ders bilgi formundan ve öğretim elemanı ifadelerinden anlaşıldığı üzere, teorik düzeyde farklı oranlara sahip vize-final sınavı uygulaması gerçekleştirilmektedir. Değerlendirme sürecine ödev, saha çalışması raporu gibi unsurların dahil edilmesinin motivasyon düzeyini ve katılımı artıracağını söylemek yanlış olmaz. Ayrıca bu durum, programın ileriye yönelik uygulanabilirliğini kolaylaştıracak, öğrenmelerin istenilen düzeyde gerçekleşmesine de katkı sağlayabilecektir.

İlgili çalışma Adnan Menderes Üniversitesi Sultanhisar Meslek Yüksekokulu Yönetim ve Organizasyon Bölümü İnsan Kaynakları Programı özelinde 'Çalışma İlişkileri' dersi öğretim programının farklı paydaşlarca değerlendirilmesi yoluyla gerçekleştirilmiştir. Ülkemizde yer alan diğer okullar özelinde de çalışmanın farklı zaman ve farklı modeller ile 
gerçekleştirilmesi ve programın ve dersin değerlendirilmesi ile daha güncel ve daha kesin yargilara ulaşılabilecektir.

\section{Öneriler}

Mevcut haliyle değerlendirildiğinde söz konusu dersi daha verimli kılma ile ilgili olarak elde edilen bulgular ışığı altında aşağıdaki işevuruk öneriler getirilebilir:

1. Öğrenciyi motive edici, yaşantı izli ve çeşitli senaryoların yer aldığı durumlar aracılığıyla dersin daha ilgi çekici hale getirilmesi sağlanabilir.

2. Çeşitli senaryolar aracılığıyla karşıt/itilaflı durumlar sunularak öğrenciler etkileşimsel bir sürece dahil edilebilir.

3. Öğrenciler farklı öğrenme/öğretim yöntem ve teknikleri aracılığıyla araştırma çalışmaları yapmaları sağlanabilir.

4. Dersin çıktılarıyla program çıktılarının öğrenciler tarafından fark edilmesini sağlayan ve kendilerini iş dünyasında hissedebilmelerine olanak sağlayan geziler düzenlenebilir.

5. Farklı alternatif/tamamlayıcı ölçme tekniklerine başvurularak öğrencilerin süreçte daha etkin bir konuma gelmeleri sağlanabilir.

\section{KAYNAKÇA}

Adnan Menderes Üniversitesi, Sultanhisar Meslek Yüksekokulu, İnsan Kaynakları Programı, Çalışma İlişkileri Dersi Bilgi Formu (2017).

http://www.akademik.adu.edu.tr/myo/sultanhisar/default.asp?idx=333430 adresinden 12.05.2017 tarihinde indirilmiştir.

BAİLEY, K. D. (1982). Methods of social research (2nd ed.). New York: The Free Press.

BİÇERLİ, M. K., ŞIŞMAN, Y., UÇKAN, B., KAYA, P.A., KOÇAK, H. ve KAĞNICIOĞLU, D. (2013). Çalışma ilişkileri. Eskişehir: Anadolu Üniversitesi.

COFFEY, A. and ATKINSSON, P. (1996). Making sense of qualitative data: Complementary research strategies, Newbury Park, CA: Sage.

COHEN, L. and MANION, L. (1994). Research methods in education (4th ed.). London: Routledge.

ÇAKICI, Z. (2010). Mesleki eğitim merkezlerinde uygulanmakta olan erkek berberliği eğitim programının değerlendirilmesi. Yayımlanmamış Yüksek Lisans Tezi, Gazi Üniversitesi Eğitim Bilimleri Enstitüsü, Ankara

DAVRAS, G. M. ve BULGAN, G. (2012). Meslek yüksekokulu (MYO) öğrencilerinin İngilizce hazırlık eğitimine yönelik tutumları: Isparta MYO turizm ve otel işletmeciliği örneği, Doğuş Üniversitesi Dergisi, 13 (2), 227 - 238

FIRAT, T. (2010). Eğitilebilir zihin engelli ögrencilere yönelik hazırlanan ilköğretim sosyal bilgiler dersi programının ögretmen görüşlerine göre değerlendirilmesi. Yayımlanmamış Yüksek Lisans Tezi. İnönü Ǘniversitesi,

KAĞNICIOĞLU, D. (2007). Çalışma İlişkileri ve İnsan Kaynaklarının İş Güvenliği. İnsan Kaynakları Yönetimi. (Ed. Uğur Dolgun), Ekin Kitabevi: 2007. 
KOCABATMAZ, H. (2011). Teknoloji ve tasarım ögretim programının değerlendirilmesi. Yayımlanmamış Doktora Tezi, Gazi Üniversitesi Eğitim Bilimleri Enstitüsü: Ankara.

KVALE, S. (1996). Interviews: An introduction to qualitative research interviewing. Thousand Oaks: SAGE.

ÖZDEMIR, S. M. (2009). Eğitimde program değerlendirme ve Türkiye'de eğitim programlarını değerlendirme çalışmalarının incelenmesi. Yüzüncü Yll Üniversitesi Eğitim Fakültesi Dergisi, 6(2).126-149

ORTAKAYA, R. (2015). Çalışma ilişkileri.

https://receportakaya.wordpress.com/2015/12/18/calisma-iliskileri/ adresinden alınmıştır.

PATTON, Q. M. (1987). How to use qualitative methods in evaluation . London: Sage Pub.

PATTON, Q. M. (1990). Qualitative evaluation and research methods (2nd ed.). Newbury Park, CA, Sage Press.

RİA, G., Evaluation Models, (E.T :26.02.2017). https://www.academia.edu/16519988/EVALUATION_MODELS

SÖNMEZ, V. ve ALACAPINAR, F. G. (2015). Örnekleriyle eğitimde program değerlendirme. Ankara: Anı Yayıncılık

UŞUN, S. (2012). Eğitimde program değerlendirme-Süreçler, yaklaşımlar ve modeller. Ankara: Anı Yayıncilık.

WOLCOTT, H. (1994). Transforming qualitative data: description, analysis, and interpretation. SAGE.

YAKAR, A. ve SARACALOĞLU, A. S. (2013). 2013 Ortaokul 5. sinıf bilim uygulamaları dersi öğretim programının Metfessel-Michael modeline göre değerlendirilmesi. Eğitimde Kuram ve Uygulama, 12(3), 769-796.

YILDIRIM, A. ŞIMŞEK, H. (2016). Sosyal bilimlerde nitel araştırma yöntemleri. Ankara: Seçkin Yayıncılık.

YÜKSEL, İ. ve SAĞLAM, M. (2014). Eğitimde program değerlendirme. Ankara: Pegem Akademi. 